\title{
Intellectual property indicators and renewable energy trends
}

ABSTRACT: Renewable energy development is crucial for resolving global warming issues and achieving sustainable development goals. The objective of this paper is to reveal renewable energy trends using statistical data to identify the most developed technologies in the field, their distribution by territory, checking the interrelation between investments in R\&D and patent activity.

The changes in total investments made in renewables are studied for 2004-2019 and the increasing trend has been observed with some fluctuations in certain years, major current investments in solar and wind energy are detected. The dynamics of international patenting activity in solar and wind technologies, geothermal and fuel cells, the total number of PCT applications over the past 10 years by geographic region are considered. The results show some differences across various renewable technologies. Solar is the most patented, wind and fuel cells are less patented but solar and wind have shown an uptrend for the last five years, while fuel cell technologies showed a decline after 2008. Geothermal is the least patented.

The comparison between investment and patent application trends in renewables undercovers some important issues - the leading role of Japan in patenting under the PCT procedure, while China is

$\bowtie$ Corresponding Author: Tetiana Sobolieva; e-mail: tetiana.sobolieva@kneu.ua

1 Management Department, Kyiv National Economic University named after Vadym Hetman, Ukraine; ORCID iD: 0000-0002-7818-145X; e-mail: tetiana.sobolieva@kneu.ua

2 Management Department, Kyiv National Economic University named after Vadym Hetman, Ukraine; ORCID iD: 0000-0002-3393-2010; e-mail: nataliia.harashchenko@kneu.ua

2020. The Author(s). This is an open-access article distributed under the terms of the Creative Commons Attribution-ShareAlike International License (CC BY-SA 4.0, http://creativecommons.org/licenses/by-sa/4.0/), which permits use, distribution, and reproduction in any medium, provided that the Article is properly cited. 
a major investor in renewable energy; the US and Europe with big investments in renewables are also leading in patent registration.

Correlation between investment in R\&D and patenting activity in the field of global renewable energy should be emphasized (correlation coefficient $R=0,849$ for 2002-2019). Since private and public investment is strongly stimulated by domestic renewable energy policies, IP indicators can help identify policy instruments and their effectiveness within the further research framework.

KEYwORDS: intellectual property, renewable energy, patent, PCT

\section{Introduction}

The Forecast published in The Global Innovation Index 2018: Energizing the World with Innovation (GII 2018) is predicting that by 2040 the global energy demand will increase by more than 30\% (WIPO 2018). The International Energy Outlook (U.S. Energy Information Administration (EIA 2019)) is predicting the increase in energy demand by $50 \%$ in 2050 compared to 2018. Asian countries with stable economic growth (countries with a high density of the population and with high business activity) are seen as the main consumers of energy resources (Sterling et al. 2017). It is expected that India will utilize up to $11 \%$ of the world energy produced by 2040 , and up to $30 \%$ of increased demand quantity (León et al. 2018).

Growth in energy consumption resulting in global challenges associated with rapid growth in carbon dioxide $\left(\mathrm{CO}_{2}\right)$ emissions and it is one of the main reasons for the Earth's climate change caused by global warming. An increase of average yearly temperature has already caused discrepancies in the planet's ecosystem and could lead to disastrous consequences for mankind. Grave impacts of significant climate change might be avoided if current energy systems were transformed.

Renewable energy sources hold the key potential to mitigate climate change by displacing greenhouse gas emissions, being an important remedy for energy substitution (reduction of mining, processing, and combustion of fossil fuels - coal, oil, and gas) (Mannan 2010; Preiss and Kowalski 2010; Edenhofer et al. 2011; Simin and Pejanović 2011). Since renewable energy supplies are mostly obtained from free ongoing sources of energy in our surroundings, they are less likely to unfavorably affect food security, nor threaten biodiversity. Renewable energy typically uses national resources to address energy security issues (Liu et al. 2016), create jobs (Komendantova and Patt 2014), and locally reduce air pollution and water consumption (Amin 2015). Renewable energy sources are more evenly distributed around the globe as compared to carbon based sources (Edenhofer et al. 2011).

Growth speed and development directions of renewables are driven by the world demographic and economic trends, countries energy policies (Dechezleprêtre and Glachant 2014; Verdolini and Bosetti 2017; Gao and Zhai 2018; Bonnet et al. 2019), fuel reserves, and their 
availability, production and utilization cost. At the same time, many factors are constraining the use of renewables (Pearce et al. 2013; Geng and Ji 2016). As most renewable energy resources are climate-dependent and influenced by seasonal variations, the discontinuity of generation is an intrinsic shortcoming (Baños et al. 2011). The current energy market design is not suited for alternative energy spreading (Guerin 2009), the diffusion of renewable energy technologies is slowed down by the patent monopoly (Raiser et al. 2017). Many countries do not have incentive policies for businesses (Zhao et al. 2014) aimed at stimulating a decrease in pollution and the use of clean energy. The cost of technologies and equipment for renewables is still high, though due to the economy on scale and strong auction competition electricity prices for wind and solar are dropping down. For the last decade prices fell by $83 \%$ for solar photovoltaics and by $49 \%$ and $51 \%$ for share wind and sea wind respectively (FS-UNEP Centre 2020), and prices per kilowatt-hour $(\mathrm{kWh})$ in many utility-scale solar photovoltaic $(\mathrm{PV})$ projects are competitive yet compare to fuel energy sources.

Renewable energy technologies development is still seen as one of the main prerequisites for speeding up the dissemination and use of alternative energy in many countries (Amin 2015). According to the EIA forecast by 2050 renewables will be the dominant source of world energy, outstripping the share of petroleum, coal, natural gas, and nuclear (EIA 2019).

Intellectual property indicators are used in alternative energy research in different dimensions, especially for innovation activity analysis. The dynamics of patent registration is periodically recorded in the reports and reviews of the World Intellectual Property Organization (WIPO 2017, 2018, 2020a and 2020b). A broader study (León et al. 2018) was conducted using the information on green patents to analyze energy technology innovations from earlier data. Based on patent information, the concentration of renewable energy technologies was determined depending on the territory, owners, and developers of renewables (Liu et al. 2016), the analysis of patent activity revealed a connection between innovation and the development of renewables, in the long run, that is, there is a lag influence over time (Geng and Ji 2016).

Patenting as an indicator of innovative activity in renewable energy is used in some studies to confirm its stimulating or inhibiting effect on the development and distribution of renewables. Thus, there is a double influence of intellectual property on the development of technologies in alternative energy: both stimulating research and development and curbing the diffusion of technologies under patent protection (Bonnet et al. 2019). Raiser et al. (2017) indicate that patents provide economic incentives for innovation, but at the same time create barriers to the implementation of improvements to previously patented technologies. Imperfect intellectual property protection is seen as a barrier to the spread of environmental innovation abroad (Dechezleprêtre and Glachant 2014). Intellectual property protection is cited as a barrier to the transfer of renewable energy technologies in China (Guerin 2009). Patents are seen as a driving force for innovation in the context of global IP protection strategies (Sterling et al. 2017). It also examines the impact of different domestic clean energy policy instruments on technology transfer (Verdolini and Bosetti 2017). On the contrary, Gao and Zhai (2018) point to a lack of significant linkages between IP policy and the increased development of renewable energy innovation. 
The state of art in the different topics related to all renewable energy technologies is described in (Guerrero-Lemus and Martı'nez-Duart 2013); it contains the analysis of patent statistics revealing future energy trends as of 2011, which are focused on further reducing energy costs from renewable technologies applying different strategies (new materials, new designs, increasing energy storage capacities, etc.), observing diverse behavior between technologies.

The practice and possibilities of patenting for selected renewable energy technologies such as biofuels are being investigated (Mannan 2010). Intellectual property law is seen as an obstacle to the diffusion and commercialization of Solar photovoltaic (PV) technology (Pearce et al. 2013). The use of patent portfolios is seen as a facilitator for attracting investment and the diffusion of Algal biodiesel technologies (Preiss and Kowalski 2010). Zhao et al. (2014) point to the impact of intellectual property flexibility on the development of the wind power industry.

Development trends in the global energy market are difficult to predict since many drivers are very volatile. Innovation activity dynamics of renewable energy technology developers based on a patent registration of intellectual property may help to indicate processes and trends mirroring the world trajectory for renewables.

The investigation of patent applications for alternative energy technologies may allow for distinguishing technologies with high $R \& D$ activities, territories with a maximum density of patented technologies, which is the objective of the conducted research. The study is also intended to reveal correlations between investments in R\&D and patent registration activities in the world. The study is based on a peer review journal analysis, reports of WIPO and Energy organizations, and statistical computation.

\section{Renewable energy dynamics}

The total world production of renewable energy demonstrates sustainable growth. Figure 1 illustrates the dynamics for the period of 2010-2018 (IRENA 2020). As we see production grew up by 2.4 billion GWh or by $56.7 \%$ in 2018 compared to 2010, reaching 6.6 billion GWh in 2018 and it constitutes around $5.5 \%$ growth per year.

The production structure of renewable energy for the year 2018 by regions is shown in Figure 2 (IRENA 2020). Asia is the main supplier of total world production (40\%), about a fifth is provided by Europe and the same is by North America, 12\% is supplied by Central America and the Caribbean. The share of each region from the rest is no more than $5 \%$ of world renewables.

Renewable energy consumption varied $17-18 \%$ of total final energy consumption globally during 1990-2015, showing a maximum of 18.1\% in 1999 and 2015. In April 2019 in the USA renewable energy sources provided $23 \%$ of power generation compared to $20 \%$ of such derived from coal running ahead of it the first time. In 2018, renewable energy represented $18.9 \%$ of the energy consumed in the EU, compared with $9.6 \%$ in 2004 and on a path to the 2020 target of 20\% (Eurostat 2020). 


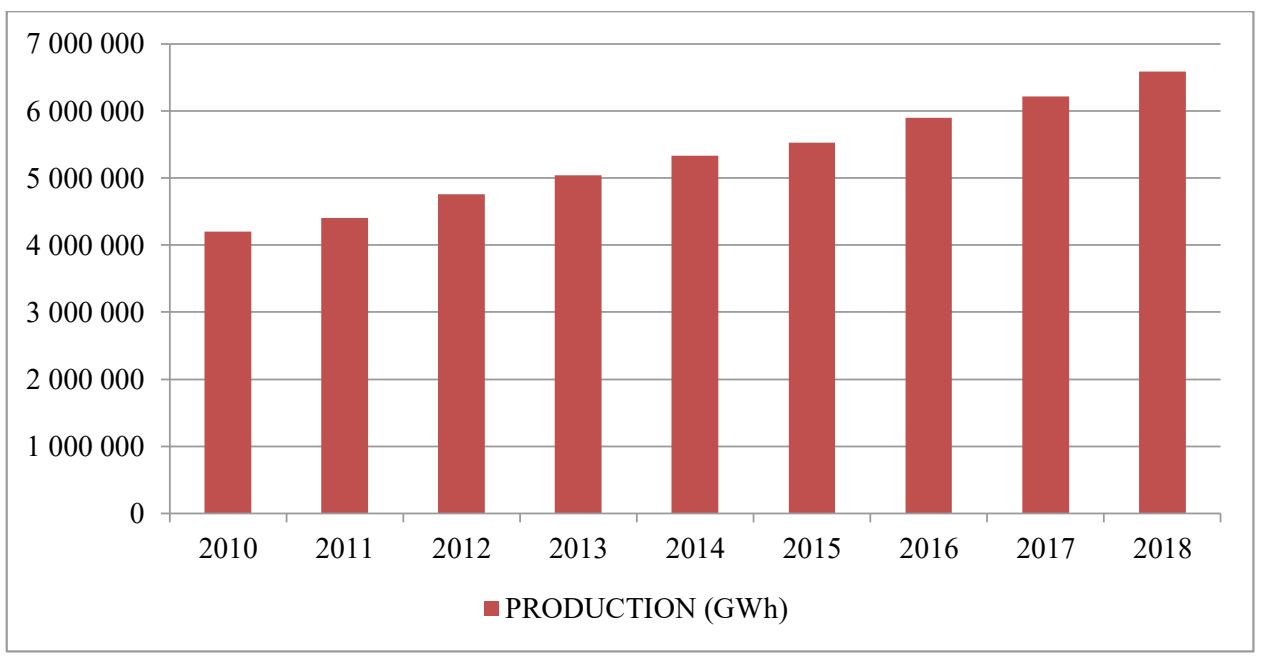

Fig. 1. Renewable energy production [GWh]

Source: based on Renewable Energy Statistics 2020 (IRENA 2020)

Rys. 1. Produkcja energii odnawialnej [GWh]

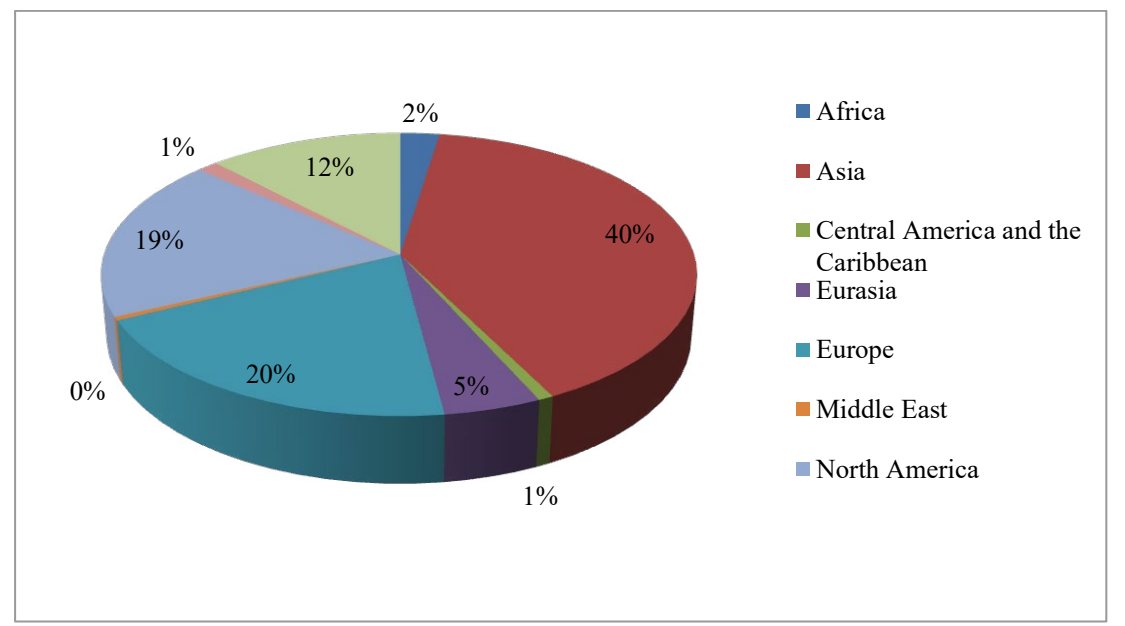

Fig. 2. Structure of renewable energy production by region in 2018 [\%]

Source: based on Renewable Energy Statistics 2020 (IRENA 2020)

Rys. 2. Struktura produkcji energii odnawialnej według regionów w 2018 r. [\%]

For the period 1990-2015 electricity production from renewable sources, excluding hydroelectric had grown exponentially - it increased 10.5 times from 156 billion kWh in 1995 up to 1.65 trillion $\mathrm{kWh}$ in 2015 (World Bank 2020). 26,3\% of electricity produced in the world done from renewables (including large hydropower plants) in 2019 (Nurton 2019). 
Globally, hydropower comprised $50.7 \%$ of cumulative installed renewable electricity capacity, followed by wind (24.5\%), solar PV and CSP (18.3\%), biomass $(5.6 \%)$, and geothermal $(0.6 \%)$ in 2017 (EERE 2018). In the first half of 2019 wind and solar energy took $50 \%$ of total US renewables instead of the traditional dominance of hydropower (Deloitte Development 2020).

According to the Global Trends in Renewable Energy Investment 2019, published by the UN Environment Programme and Bloomberg NEF, for the period 2014-2018 total yearly investments in renewables were over USD 250 billion. The cumulative investment for 2010-2018 is USD 2.8 trillion averaging 284 billion yearly (FS-UNEP Centre 2020). Total yearly investment in renewable energy in 2019 amounted to USD 301.7 billion, which is 2\% more than in 2018.

The investment structure for 2019 by types of renewables is shown in Figure 3, by regions in Figure 4. Over $90 \%$ of investments are made in wind and solar energy development (47\% each). There were USD 141 billion of investments made in solar and USD 142.7 billion in wind. Thus 2019 investment structure is described by equal investments in solar and wind that differ from previous periods - in the period 2004-2009 there were significantly more investments made in wind than in solar (by $1 / 3$ more), in the period 2010-2018 $-1 / 2$ more in solar than wind.

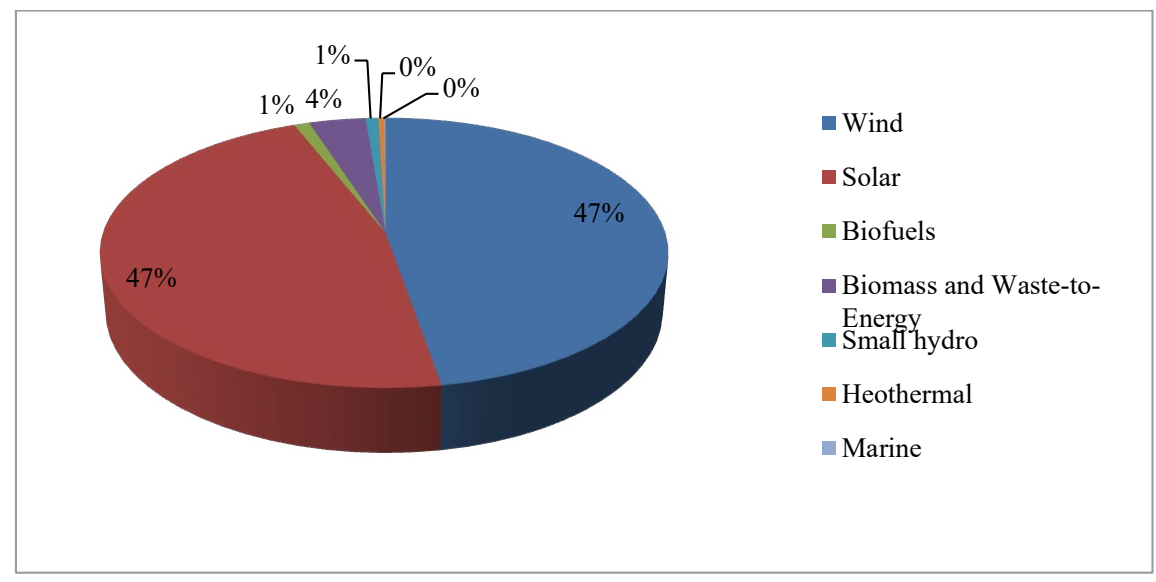

Fig. 3. Investments in renewable energy by sector in 2019, world [\%] Source: based on (FS-UNEP Centre 2020)

Rys. 3. Światowe inwestycje w odnawialne źródła energii według ich rodzajów 2019 r. [\%]

Geography of investments is the following - China dominates with USD 90.1 billion which is $30 \%$ of global investments; the USA and Europe are financing renewables intensively ( $20 \%$ and $19 \%$ respectively). India with $4 \%$ and Brazil with $2 \%$ also stand out as significant investment contributors to the global development of green energy.

Different stages of technology development and application are represented by the dominance of specific types of investments (see Table 1). The technology research stage is lead mostly by government investment, with less involvement of corporate balance sheet and little venture capital. Technology development is driven by corporate investments and more considerable ven- 


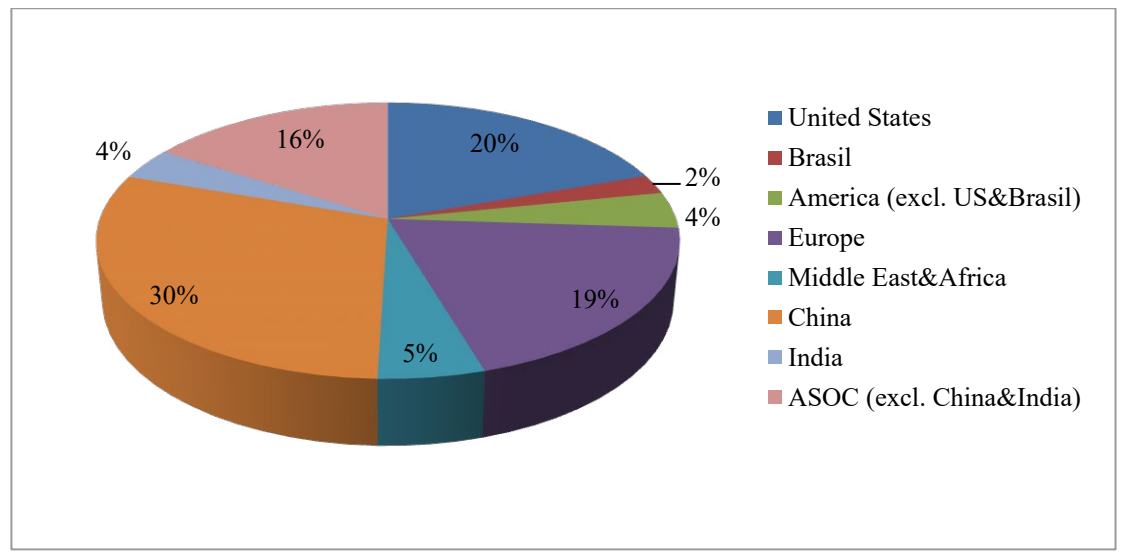

Fig. 4. Investments in renewable energy by region [\%] Source: based on (FS-UNEP Centre 2020)

Rys. 4. Inwestycje w odnawialne źródła energii według regionów [\%]

TABLE 1. Funding stages of renewable energy technology

TABela 1. Etapy finansowania technologii energii odnawialnych

\begin{tabular}{|c|c|c|c|c|c|c|c|}
\hline Stage/ Involved investment $(+)$ & 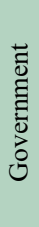 & 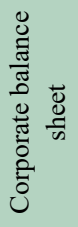 & 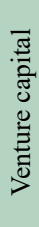 & 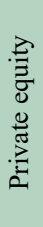 & 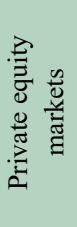 & 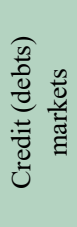 & 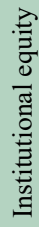 \\
\hline Technology R\&D & + & + & + & & & & \\
\hline Technology research & + & + & & & & & \\
\hline Technology development & & + & + & & & & \\
\hline Manufacturing (scale-up) & & & + & + & + & & \\
\hline Roll-out (asset finance) & & & & + & + & + & \\
\hline Acquisitions and refinancing & & & & & & + & + \\
\hline
\end{tabular}

Source: based on (FS-UNEP Centre 2020).

ture capital. Private equity investments may also be involved at this stage, but this mainly is used in the manufacturing (scale-up) of the technology stage and "roll-out". Private equity markets and Credit (debts) markets are other investment sources used on scale-up and roll-out stages. Institutional equity is the main source of acquisitions and refinancing.

For patent activity analysis in the field of IP registration in renewables technology development and deployment, the dynamics of total investments was synthesized. The first phase (R\&D) of the value chain is seen as technology research and technology development united. Those two constitutes of the first stage are characterized by a big number of granted patents. 
Figure 5 shows world investment dynamics in the R\&D of renewable energy technologies for the last 15 years. A significant increase in investments was detected in 2010-2012 with a pick of USD 95.8 billion in 2011. The next four years' investments were dropped down and renewed to grow since 2017. Investments in 2019 grew by USD 15.2 billion (23.4\%) compare to 2018, amounted to USD 80.1 billion. Government investment had the largest share in technology development investment until 2016, with corporate finance dominating over the last three years. Venture capital increased by $508 \%$ and amounted to USD 1.2 billion in 2019 after a significant reduction to USD 0.2 billion in 2018. In the period 2004-2019 compound annual growth rate (CAGR) for government investment was $8 \%$, for corporate R\&D and venture capital was $9 \%$ and $10 \%$ respectively.

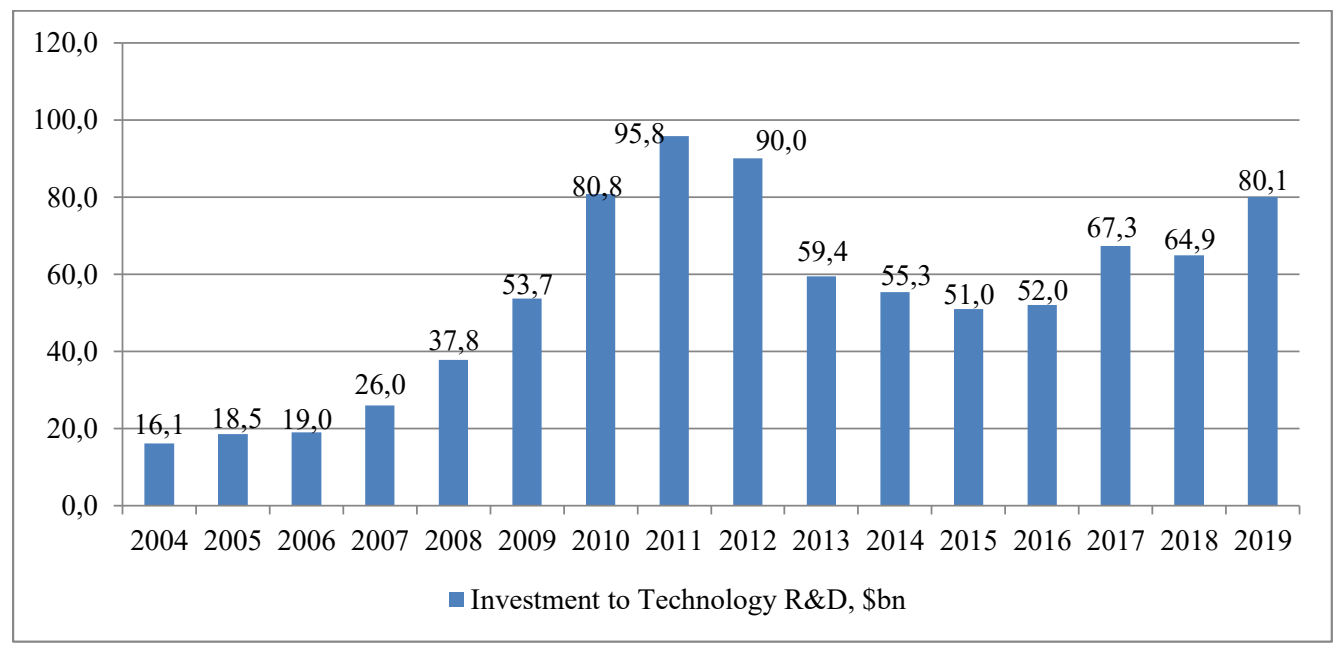

Fig. 5. Investment in R\&D of renewable energy technologies, world [USD billion] Source: based on (FS-UNEP Centre 2020)

Rys. 5. Światowe inwestycje w badania i rozwój technologii energii odnawialnych [mld USD]

Regarding renewable energy, the rapid growth of its production was achieved mainly by government support policies (Heshmati et al. 2015). Tariffs, finances, tax policies, and energy efficiency are used by states to develop renewable energy. National strategies to support sustainable development have been implemented in most OECD countries through the use of a wide range of policies to regulate environmental, science and technology, transport and competition issues (OECD 2011). The increase in renewable energy consumption was also influenced by the fact that at least 109 countries adopted renewable energy support policies until 2012 (Martinot and Sawin 2012). Since 2015 when Global Sustainable Development Goals (SDGs) were adopted by the UN, countries are prompting to ensure that energy is clean, affordable, available, and accessible to all (Goal 7) and $\mathrm{CO}_{2}$ emissions keep reducing (Goal 13) translating SDGs in their renewable energy policies. Becoming the world's first climate-neutral continent by 2050 is the 
objective behind the European Green Deal seeing as an integral part of the European Commission's strategy to implement the United Nation's 2030 Agenda and the sustainable development goals (Eurostat 2020).

The United Nations General Assembly declared 2014 to 2024 to be the Decade of Sustainable Energy for All (UN GA 2012), and the High-Level Group on Sustainable Energy for All (SE4ALL) was set declaring three main objectives to be achieved by 2030: ensure universal access to modern energy services; double the global rate of improvement in energy efficiency, and double the share of renewable energy in the global energy mix. In the working paper Doubling the Global Share of Renewable Energy: A Roadmap to 2030 - REmap 2030 (IRENA 2013) a critical importance of international cooperation for countries willing to find sustainable energy solutions and meet energy needs without negatively affecting the climate was highlighted. Those policy intentions initiated by international organizations were fixed by adopting Sustainable Development Goals by all United Nations Member States in 2015, especially goal 7 and 13 and thus had become drivers for resuming renewable energy development what PCT applications made may evident.

\section{Patenting activities in renewable energy technologies}

Patent information is a valuable source for indicating future directions of technology development, geographic spread, and feasible promotion strategies for international markets.

Innovation in green technologies in general barely rose in 2019, the number of PCT applications containing at least one IASC code related to the "green" energy sector increased only by $1.3 \%$ compared to 2018 . This is below the peak reached in 2016 (17,880 applications) and represents just over $6 \%$ of the total number of PCT applications submitted in 2019 (WIPO 2020a). More than $76 \%$ of all "green" PCT applications were submitted by countries such as Japan, China, the US, Germany, and the Republic of Korea with only China and the Republic of Korea showing increases. Moreover, China showed an increase in PCT applications in most categories related to "green" energy; in recent years China also is seen as the world's patent leader of environmentally friendly transport technologies (WIPO 2020b). WIPO Director General Francis Gurry stated that a surge in "green" technologies is needed to combat climate change.

Published PCT applications for renewables were divided into four branches: solar, wind energy, fuel cell, and geothermal (see Fig. 6). Patent applications for wind energy with the maximum in 2012, substantially decreased by 2016 (914 applications in 2012 against 508 in 2016), then started to grow again (807 patent applications in 2019). Fuel cell technology patents registered under the PCT procedure reached the maximum in 2008, demonstrating a slight decline of innovation activity in the area over the next ten years. Geothermal energy technology is the least patented fluctuating between 35 and 53 applications per year since 2010 . 


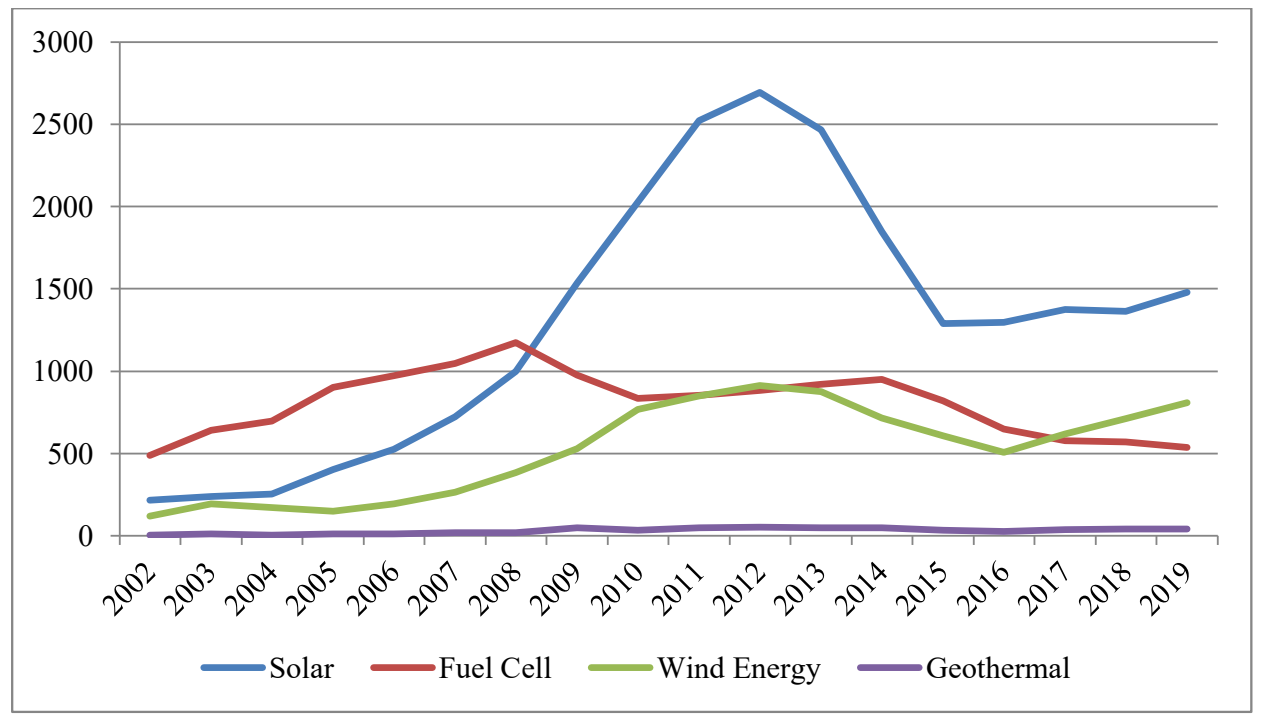

Fig. 6. Number of PCT publications for renewable energy technologies by sector Source: based on (Nurton 2019)

Rys. 6. Liczba opublikowanych PCT dotyczących technologii odnawialnych według ich rodzajów

Solar energy technology is the most being patented among renewables - totally between 2012 and 2019 the number of patent applications had increased 7 times (Nurton 2019). The biggest number of patent applications was fixed in 2012 (2691 applications), it was high also in 2011 (2522 applications), and in 2013 (2465 applications). Moreover, since 2008, investments in solar energy have more than doubled, which may explain an increase in patenting activity in this sector.

Some experts explain the drastic drop in the number of solar energy PCT applications observed in 2013-2015 as caused by two reasons (WIPO 2017). The first is that many companies left out a business that means a reduction of the number of potential applicants; although industry players remained in the solar photovoltaic (PV) market have increased filing for patents. The second reason is the decrease in the internationalization of patents, that is, the decrease in the number of patents that are registered both in national jurisdiction and at the international level. Although this trend is not typical for all regions. The US is the most active in applying under the international route, European and Japanese, and Korean applicants are less active, and the least active are Chinese ones - this causes a drop-down in registration under PCT although China is demonstrating the growth of patent applications under national routes.

The total number of patent applications for renewables over the past decade (from 2010 to 2019 ) by the country of origin (Fig. 7) indicates the leading role of Japan in patenting under the PCT procedure. The US has been actively patenting inventions in renewables ( $22 \%$ of cumulative number for the past ten years), Germany (13\%), the Republic of Korea, and China (9\% each) are also rather active in the area. Denmark is the leader in wind energy patenting, the US - in geothermal technologies. 


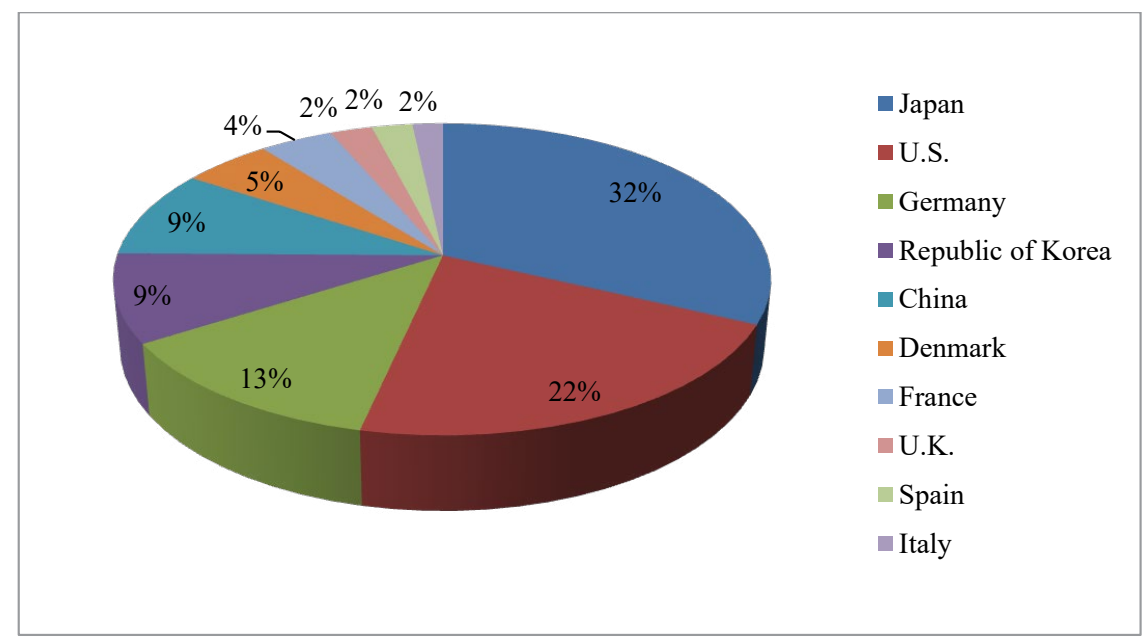

Fig. 7. PCT applications for renewables over the decade 2010 to 2019 by geographic region [\%] Source: based on (Nurton 2019)

Rys. 7. Aplikacje PCT dla OZE w latach 2010-2019 według regionu geograficznego [\%]

Patent family registration statistics differ a lot from patent registration under PCT. The patent family consists of patent applications interlinked by priority claim and the same or similar technical content, for example, in the case of the same invention registration in several countries. China is an undoubted leader in patent families registered $(45,472$ patents in the period 2013-2017) following by Japan with 21,386 applications for the same period (Nurton 2019). Such a significant difference in statistics is because very many patents are registered only in the territory of the applicants' countries without filing an application for international registration under the PCT procedure.

By comparing Figure 7 with Figure 4 we may derive the inference that three regions leading in investments (US, China, and Europe) are also leading in patent registration, but China is registering a lot of patents domestically not under the PCT procedure. However, the dominance of Japan in PCT patent applications for renewables is not linked with investment activities.

Comparison of dynamics of the total number of PCT applications filed and published for renewables and investments in research and development of renewable energy technologies (see Fig. 8) for the period 2002-2019 shows that two indicators are synchronized with the correlation coefficient $\mathrm{R}=0.849$. Based on the visible interrelation of two sets of data and having extrapolated the growth in R\&D investments the increase of patent applications under PCT may be predicted for the next few years. 


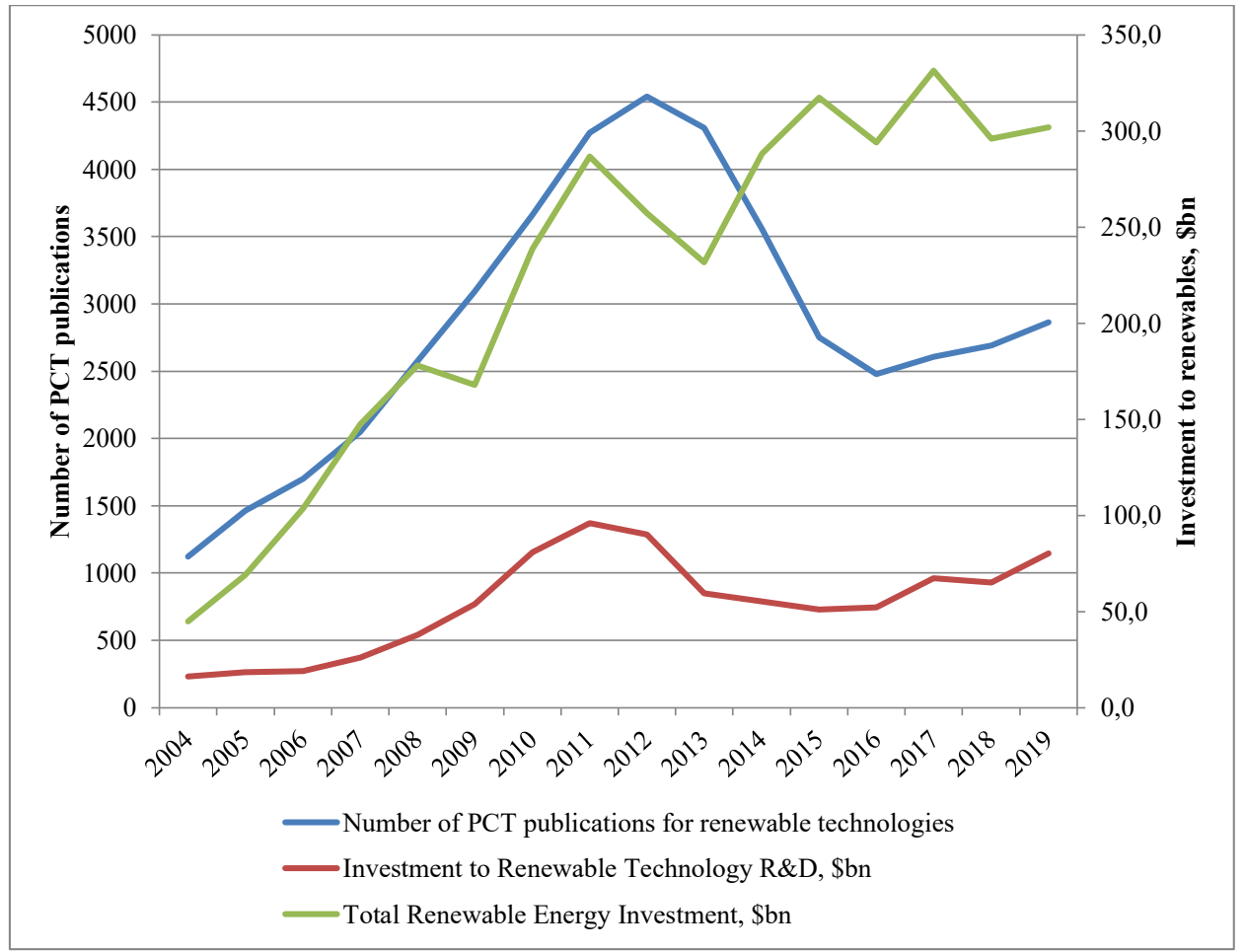

Fig. 8. PCT publications and investment in renewable technologies Source: based on (Nurton 2019; FS-UNEP Centre 2020)

Rys. 8. Publikacje PCT i inwestycje w technologie odnawialne

\section{Conclusion}

Energy production (Fig. 1), as well as energy use, is growing and will continue to grow according to the forecasts for the next decades (WIPO 2018; EIA 2019). The main suppliers (Fig. 2) as well as consumers of energy resources will be Asian countries, primarily China and India (León et al. 2018).

Total investments in renewable energy sources show an increasing trend (Fig. 8) with some fluctuations in certain years. Investments in renewable technologies $R \& D$ have shown wave-like dynamics with the peak in the period 2010-2012 (Fig. 5), followed by a decline and renewed growth over the past three years. China is a major investor in renewable energy. The US, Europe, the Republic of Korea, and India also stand out among the major financial donors of this alter- 
native energy sector (Fig. 4). Almost all investments (over 90\%) are directed to the development of solar and wind energy (Fig. 3).

Renewable energy policies of countries (including state research and development support, innovation, finances, and regulations) are seen as an important driver for renewables growth. International cooperation within the Sustainable Energy for All (SE4ALL) initiative framework will contribute to remedying shortfalls in forging the renewable energy future by countries.

Patent data is a valuable source for understanding processes in innovation technologies and industries. Such information is crucial for the identification of the state of art in a certain field and so is for predicting future technology trends and $R \& D$ directions. The research results indicate the following tendencies in the field of renewables patenting and renewable energy sources technology development. The total number of patent applications showed the rise and falls over the past 15 years, cumulating 45727 applications for the period 2004-2019. The patenting of solar and wind energy technologies shows an increasing dynamic with particularly high activity in the period 2010-2014. Solar energy technology is the most being patented with a 7 times increase for the period of 2012-2019, but with a significant drop in 2013-2015, caused by market players' behavior. Patent applications for wind energy show similar fluctuations - growth to the maximum in 2012, substantially decreased by 2016, and then started to grow again. Geothermal energy technology is the least patented with small wavering. Patenting under the international route of fuel cell technologies shows a downtrend after 2008. China is the leader in renewables patenting under the national route. The leaders in patenting under PCT are Japan, the US, Germany, the Republic of Korea, and China (Fig. 7).

Considering the importance of alternative energy sources in resolving the issue of increasing energy demand, climate mitigation, and reduction of environmental pollution for sustainable development, special attention should be paid to the decrease in the number of PCT applications after 2013. Comparison of the dynamics of total investments in renewable energy, including investments in R\&D, with published PCT patent applications for the period 2004-2019 shows the interrelation between investment and patenting (Fig. 8). Investment in R\&D has a tight correlation with PCT patent applications (0.849).

As investment and embedded patent activity are policy dependent, new policy initiatives at the global level on renewable energy development (SE4ALL, SDGs) may trigger an increase in investments and patent applications for the next decade.

IP indicators are important to track the past and foresee the future evolution of the energy system. Further investigation of patenting activities in renewable energy developments may enhance the technology intelligence approach helping policymakers and firm managers build up roadmaps for future movements. 


\section{References}

Amin, Z.A. 2015. How Renewable Energy Can Be Cost-Competitive. Sustainable Energy 3, Vol. LII. [Online] https://www.un.org/en/chronicle/article/how-renewable-energy-can-be-cost-competitive [Accessed: 2020-07-22].

Baños et al. 2011 - Baños, R., Manzano-Agugliaro, F., Montoya, F., Gil, C., Alcayde, A. and GómEZ, J. 2011. Optimization methods applied to renewable and sustainable energy: A review. Renewable and Sustainable Energy Reviews 15, pp. 1753-1766.

Bonnet et al. 2019 - Bonnet, C., Hache, E., Seck, G.S., Simoën, M. and Carcanague, S. 2019. Who's winning the low-carbon innovation race? An assessment of countries' leadership in renewable energy technologies. International Economics 160, pp. 31-42.

Dechezleprêtre, A. and Glachant, M. 2014. Does Foreign Environmental Policy Influence Domestic Innovation? Evidence from the Wind Industry. Environmental and Resource Economics 58(3), pp. 391-413.

Deloitte Development LLC 2020. Renewable energy industry outlook. 10 p. [Online] https://www2.deloitte.com/content/dam/Deloitte/us/-Documents/energy-resources/us-2020-renewable-energy-industry-outlook.pdf [Accessed: 2020-06-27].

Edenhofer et al. 2011 - Edenhofer, O., Pichs-Madruga, R., Sokona, Y., Seyboth, K., Matschoss, P., Kadner, S., ... von Stechow, C. 2011. Renewable Energy Sources and Climate Change Mitigation. Cambridge: Cambridge University Press.

EERE 2018. 2017 Renewable energy data book. Energy efficiency and renewable energy. US Department of Energy.

EIA 2019. U.S. Energy Information Administration. INTERNATIONAL ENERGY OUTLOOK 2019. [Online] https://www.eia.gov/outlooks/ieo/ [Accessed: 2020-07-22].

Eurostat 2020. Renewable energy statistics by Eurostat. [Online] https://ec.europa.eu/eurostat/statisticsexplained/index.php/Renewable_energy_statistics [Accessed SE4ALL: 2020-06-26].

FS-UNEP Centre 2020. Global Trends in Renewable Energy Investment 2020 (Frankfurt am Main) Frankfurt School of Finance \& Management gGmbH -UNEP Centre/BloombergNEF. [Online] http://www. fs-unep-centre.org [Accessed: 2020-07-18].

GAO, X. and ZHAI, K. 2018. Performance evaluation intellectual property rights policy system of renewable energy in China. Sustainability (Switzerland) 10(6), DOI: 10.3390/su10062097.

GENG, J. and JI, Q. 2016. Technological innovation and renewable energy development: Evidence-based on patent counts. International Journal of Global Environmental 15(3), pp. 217-234.

GII 2018. Panel Discussion: Innovate Now for a Cleaner, Greener Future. [Online] https://www.wipo.int/ pressroom/en/news/2018/news_0005.html [Accessed: 2020-06-27].

Guerrero-Lemus, R. and Martinez-Duart, J.M. 2013. Renewable Energies and $\mathrm{CO}_{2}$ : Cost Analysis, Environmental Impacts and Technological Trends. DOI: 10.1007/978-1-4471-4385-7.

GUERIN, T.F. 2009. An assessment and ranking of barriers to doing environmental business with China. Business Strategy and the Environment 18(6), pp. 380-396.

Heshmati et al. 2015 - Heshmati, A., Abolhosseini, S. and Altmann, J. 2015. The development of renewable energy sources and its significance for the environment. Springer, pp. 151-152. [Online] https:// www.springer.com/gp/book/9789812874610 [Accessed: 2020-11-25].

IRENA 2013. Doubling the Global Share of Renewable Energy: A Roadmap to 2030, Working Paper, January 2013, IRENA, Abu Dhabi, 60 p.

IRENA 2020. Renewable Energy Statistics 2020 The International Renewable Energy Agency, Abu Dhabi. $408 \mathrm{p}$. 
Komendantova, N. and Patt, A. 2014. Employment under vertical and horizontal transfer of concentrated solar power technology to North African countries. Renewable and Sustainable Energy Reviews 40, pp. $1192-1201$.

León et al. 2018 - León, L.R., Bergquist, K., Wunsch-Vincent, S., Xu, N. and Fushimi, K. 2018. Measuring innovation in energy technologies: green patents as captured by WIPO's IPC green inventory. Economic Research Working Paper 44, WIPO, 28 p.

Liu et al. 2016 - Liu, Y., Hu, Z. and Liu, Z. 2016. Pattern of patent - based ond renewable energy technology innovation in China. International Journal of Earth Sciences and Engineering 9(4), pp. $1815-1823$.

ManNAN, R. 2010. Intellectual property landscape and patenting opportunity in biofuels. Journal of Commercial Biotechnology 16(1), pp. 33-46.

Martinot, E. and SAwin, J. 2012. Renewables global status report. Renewables 2012 Global Status Report, REN21. [Online] http://www.martinot.info/REN21_GSR2012.pdf [Accessed: 2020-06-27].

NurTON, J. 2020. Patenting trends in renewable energy. WIPO Magazine 1. [Online] https://www.wipo.int/ wipo_magazine/en/2020/01/article_0008.html [Accessed: 2020-06-27].

OECD 2011. Better policies to support eco-innovation. OECD Publishing, Paris.

Pearce et al. 2013 - Pearce, J.M., Zhang, C., Rozario, J. and Gwamuri, J. 2013. The viability of nanotechnology-based on InGaN solar photovoltaic devices for sustainable energy generation. Materials Research Society Symposium Proceedings 1558. MRS Spring Meeting. San Francisco, CA. United States. 1-5 April 2013.

Preiss, M.R. and KowalSki, S.P. 2010. Algae and biodiesel: Patenting energized as green goes commercial. Journal of Commercial Biotechnology 16(4), pp. 293-312.

RAISER et al. 2017 - RAISER, K., NAIMS, H. and BRUHN, T. 2017. Corporatization of the climate? Innovation, intellectual property rights, and patents for climate change mitigation. Energy Research and Social Science 27, pp. 1-8.

SE4ALL - Sustainable Energy for All, 2012. A Global Action Agenda: Pathways for Concerted Action towards Sustainable Energy for All, The Secretary-General's High-Level Group on Sustainable Energy for All, April 2012, United Nations, New York.

Simin, M.J. and Pejanović, R. 2011. Intellectual property protection and biodiesel. Proceedings of the $24^{\text {th }}$ International Conference on Efficiency, Cost, Optimization, Simulation and Environmental Impact of Energy Systems. Novi Sad, Serbia 4-7 July, pp. 3194-3198.

Sterling et al. 2017 - Sterling, D.A., Frueauf, J.B. and Dudley, B.M. 2017. Global ip strategies for procuring and protecting green innovations: A focus on Europe, Brazil, China, and the US. European Biomass Conference and Exhibition Proceedings 2017 (25). June 2017, pp. 1648-1656.

UN GA (United Nations General Assembly) 2012. Decade of Sustainability for All 2014-2024, GA/11333 EN/274, UN GA, New York.

Verdolini, E. and Bosetti, V. 2017. Environmental Policy and the International Diffusion of Cleaner Energy Technologies. Environmental and Resource Economics 66(3), pp. 497-536.

WIPO 2017. World Intellectual Property Report 2017. Intangible Capital in Global Value Chains. [Online] https://www.wipo.int/edocs/pubdocs/en/wipo pub 944 2017.pdf [Accessed: 2020-07-28].

WIPO 2018. World Intellectual Property Indicators 2018. [Online] https://www.wipo_pub_941_2018.pdf [Accessed: 2019-03-03].

WIPO 2020a. World Intellectual Property Day 2020: Green Innovation Surge Needed to Address Climate Change, New WIPO Figures Show. [Online] https://www.wipo.int/pressroom/en/articles/2020/article_0007.html [Accessed: 2020-06-27].

WIPO 2020b. IP Statistical Data based on Using the WIPO Environmental Register of the International Patent Classification (IPC). [Online] https://www.wipo.int/export/sites/www/pressroom/ru/documents/ pr_2020_851_annex.pdf [Accessed: 2020-06-27]. 
World Bank 2020. Renewable energy consumption ( $\%$ of total final energy consumption) World Bank. [Online] https://data.worldbank.org/indicator/-EG.FEC.RNEW.ZS [Accessed: 2020-06-27].

Zhао et al. 2014 - Zhао, Z.-Y., Zhu, J. and Zuo, J. 2014. Sustainable development of the wind power industry in a complex environment: A flexibility study. Energy Policy 75, pp. 392-397.

\section{Wskaźniki własności intelektualnej i trendy w zakresie energii odnawialnej}

\section{Streszczenie}

Rozwój energii odnawialnej ma kluczowe znaczenie dla rozwiązania problemów związanych z globalnym ociepleniem i osiągnięcia celów zrównoważonego rozwoju. Zadaniem niniejszego artykułu jest ujawnienie trendów energii odnawialnej przy użyciu danych statystycznych w celu zidentyfikowania najbardziej rozwiniętych technologii $\mathrm{w}$ tej dziedzinie, ich terytorialnej dystrybucji, sprawdzenie zależności między inwestycjami w B + R a działalnością patentową.

Zbadano jak zmieniały się nakłady inwestycyjne ogółem w odnawialne źródła energii w latach 2004 -2019 i zaobserwowano tendencję wzrostową z pewnymi wahaniami w niektórych latach. Obecnie zauważyć można popularność dużych inwestycji w energię słoneczną i wiatrową. Uwzględniono dynamikę międzynarodowej działalności patentowej w zakresie technologii słonecznych i wiatrowych, geotermii i ogniw paliwowych, całkowitą liczbę wniosków PCT w ciągu ostatnich 10 lat w podziale na regiony geograficzne. Wyniki pokazują różnice w zależności od badanych technologii odnawialnych. Najczęściej patentowane są technologie ogniw słonecznych, zaś najmniej patentów dotyczy technologii wiatrowych i ogniw paliwowych, ale energia słoneczna i wiatrowa wykazują tendencję wzrostową w ciągu ostatnich pięciu lat, podczas gdy technologie ogniw paliwowych wykazały spadek po 2008 r. Najmniej opatentowanych rozwiązań dotyczy technologii geotermalnych.

Porównanie trendów inwestycyjnych i patentowych dotyczących odnawialnych źródeł energii ujawnia kilka ważnych kwestii: wiodącą rolę Japonii w patentowaniu w ramach procedury PCT, podczas gdy Chiny są głównym inwestorem w odnawialne źródła energii; Stany Zjednoczone i Europa z dużymi inwestycjami w odnawialne źródła energii również przodują w rejestracji patentów.

Należy podkreślić korelację między inwestycjami w B + R a działalnością patentową w zakresie energetyki odnawialnej (współczynnik korelacji $\mathrm{R}=0,849$ dla lat 2002-2019). Ponieważ inwestycje prywatne i publiczne są silnie stymulowane przez krajową politykę w zakresie energii odnawialnej, wskaźniki IP (Intellectual Property indicators) mogą pomóc w określeniu instrumentów polityki i ich skuteczności w toku dalszych badań.

SŁowa KLUCZowe: własność intelektualna, energia odnawialna, patent, układ o współpracy patentowej (PCT) 